DOI: $10.15503 /$ jecs20142.7.18

Journal of Education Culture and Society No. 2_2014

\title{
PROTESTANT ETHICS IN ACADEMIA
}

\author{
ANNA MARIA KUCHARSKA, \\ Faculty of Pedagogy, University of Wroclaw, \\ ul. J. W. Dawida 1, Wroclaw, Poland \\ E-mail address: annamaria.kucharska@gmail.com
}

At this moment rules are not interesting to us. We must play the match in any case, so we will respect them according to the best traditions of sporting spirit until we find the place where they can be bent or broken for our benefit. Terry Pratchett Unseen Academicals

\begin{abstract}
Academic ethics has recently become an important issue in Poland. With changes in the Polish law on higher education a new approach to ethics of students and academics has been presented. As a PhD student and young researcher, I am personally interested in the introduced changes. This article seeks to examine professional academic ethics in terms of two chosen theories, that is, the Protestant work ethic of Max Weber and its adaptation to the academic environment by Robert K. Merton. I situate both theories in the Polish context of shaping the academic ethos. In my deliberations I recall Dietrich Bonhoeffer's works as fundamental for the Protestant work ethos values, which are honesty, reliability and diligence. Additionally I present their religious as well as non religious aspects. With such theoretical foundations, I attempt to evaluate the risks and violations in the ranks of Polish academics. The theoretical basis and the collected data enable me to put forward the claim that it is not feasible in Poland to follow the Western model of work ethics. Instead, it has to be built from scratch. To start this process, we need to consider the value of responsibility as a crucial category not only for the process of academic ethos formation, but also for everyday life from the early years.

Keywords: Higher education, academia, academic teacher, ethics, work ethos, Protestantism, Max Weber, Robert K. Merton, Dietrich Bonhoeffer

The aim of this article is to present Weber's concept of Protestant ethical principles, as expressed in the approach of Robert K. Merton, within the context of the Polish academic community. I argue that these principles are largely absent, having never taken root in the broader context of Polish culture. In the article I discuss this issue both with respect to groups of students, as well as to academic teachers and researchers. I also attempt to assess opportunities and risks related to the future of the Polish academic ethos. I argue that building an academic community based on responsibility provides an opportunity to create and disseminate healthy ethical practices within the academic environment.
\end{abstract}


While defining the term "ethics", philosophers and other scholars in the field of social sciences and humanities take the opportunity to show off their erudition. The meaning of the term is not that complicated, though. For the purposes of this paper, I use Freido Ricken's definition of ethics, whereby "ethics develops methodically and thematically (...). [It encompasses] variously understood justifications. Therefore ethics is a philosophical examination of morality; it is a branch of philosophy, which deals with justifying morality" (Ricken, 2011, p. 9) ${ }^{1}$. Karol Wojtyła, for his part, wrote about ethics even in more terms, classifying it as normative: ethics "defines norms, formulates judgments about what is good and what is bad and justifies them, that is to say it explains why it is so" (Sarnowski, \& Fryckowski, 1993, p. 11). Ethics can thus be understood as a branch of philosophy that deals with justifying a hierarchy of values, giving it a positive or negative appraisal. Ethos, on the other hand, is defined in the dictionary in three different ways: " 1 . lifestyle and moral norms, overall socially accepted and assimilated by a particular social group, designating the behaviour of its members; the lifestyle characteristic of a particular social group, which distinguishes it from others groups. 2. The "spirit« of a culture, which unifies its members around basic values accepted by a group majority. 3. a pattern of processes and emotional behaviour typical of most group members." (Olechnicki, \& Załęcki, 2000, p. 67). In other words, ethos can be equated with lifestyle and behaviour rules resulting from a specific hierarchy of values. For work ethos the core value around which norms, goals, myths and symbols of a particular environment are organised is work itself (Jacher, \& Swadźba, 2002, pp. 146-149). The discussion that follows will refer primarily to work ethics and ethos in the academic environment.

The teaching profession is sometimes included in the so called public trust professions (e.g. doctors, lawyers, architects or psychologists), in which work ethics plays an incredibly important role (Polish Teachers Association, 2010). Technically, the teaching profession does not have this status. However, it is commonly perceived by society to be on a par with with other public trust professions (Research International Pentor, 2008). The public trust professions entail social responsibility. It is assumed that tasks assigned to people performing them have a special character, in particular in the context of implementing the public interest standard (Teachers Ethic Code).

According to this, representatives of such professions are required to be ethically and morally impeccable. Until not so long ago candidates for the teaching profession were obliged to submit a moral certificate as proof of their unblemished reputation. In the contemporary world, such requirements seem inadequate, albeit society still expects that the educators of the next generation will set a good moral example for young people.

One of the basic principles/priorities for teachers is their pupils' well-being, therefore the other person is always in the centre of teachers' professional activity (Polish Teachers Association, 2010). Moreover, the ethics of this professional group is always subject to external judgement, be it parents, other teachers, educational authorities (for example, regional Boards of Education), academia or members of their particular community, who though on the surface are not directly interested, are nevertheless affected by the results of the educational approach. This implies the responsibility of a teacher as a significant person who plays an important role in the moral and ethical development of his/her pupils (Czajkowska, 2004, pp. 487-492).

All quotations from Polish sources in this paper were translated by the author. 
In the "teacher" category, there is also a place for academic teachers (lecturers or professors), although this is a specific version of this profession. Jerzy K. Thieme points to a division into lecturers and researchers-lecturers, as indicated in the Act on Higher Education. The duties of the first group are limited to teaching, while the second group, which is significantly larger in Poland, has duties which go beyond teaching. Besides didactics one person might have an administrative position and, moreover, he or she always works as a researcher, whose task is to describe reality, construct procedures, conduct research, publish results, write articles, explain correlations, explore, examine and cognise (Thieme, 2009, p. 220). Ethics is equally important for the latter role and its scarcity may lead to catastrophic results, not only for a person or a limited group of recipients, but, more generally, for the development of science and knowledge. The concept of work ethics or professional ethics was first formulated by Max Weber. M. Weber dealt mainly with the issue of capitalism and its links with the dominant religious confession of the social class, which at the time was made up of wealthy bourgeois city residents. His considerations are based on the thesis that countries dominated by Protestants develop better economically. M. Weber's fundamental assumption constitutes a theological justification for the Protestant work ethic, most fully realized in Calvinist streams, but also found in the others (Weber, 1976, pp. 108-114). He provided many examples confirming his thesis, proving at the same time that political and historical situations did not make the decisive impact (Weber, 1976, for example: pp. 57-58), nor did social conditions. As he wrote, "(...) the Protestants (...) both as a ruling class and as ruled, both as majority and minority, have shown a special tendency to develop economic rationalism which cannot be observed to the same extent among Catholics either in the one situation or in the other" (Weber, 1976, pp. 39-40). He pointed to the religious aspect of devotion to profession, which has biblical roots and is anchored in interpretations of a particular religious denomination. The concept of the call to salvation (an effectual calling) (Weber, 1976, pp. 114-119) is most conspicuously present in the Calvinist movements. However, it has to be noted that these movements' links to economy obviously do not stream directly from John Calvin's teaching. The biblical basis is mostly found in St. Paul's letters: "Whatever you do, work at it with all your heart, as working for the Lord, not for human masters, since you know that you will receive an inheritance from the Lord as a reward. It is the Lord Christ you are serving" (The Holy Bible, Colossans 3, 23-24) ${ }^{2}$. The author of the Polish introduction to The Protestant Ethics elaborates the above concept in the following words: "(...) Religion is not desecrated and, at the same time, a sacralisation of work occurs that until now was contrasted with prayer as something less worthy and sublimed. To parody the medieval motto "pray and work", it is appropriate to say that in Protestantism this motto is replaced by "pray working «" (Weber, 1994, p. XIX). In this way, a mental shift takes place: job, profession and everyday duties are to belong to the sacral sphere. Weber identified profession with calling (Weber, 1976, p. 79) and still today in Protestant circles it is understood in that way. Os Guinness in his book The Call focused on this understanding of calling, underlining that the first human calling is to follow Christ (Guinness, 1998, pp. 24-25), whereas the next step is to live in accordance with "what you are" (Guinness, 1998, pp. 46-54), mostly with respect to one's profession. In the Polish cultural context, we have gone through the Industrial Revolution and intensification of urbanisation

2 Similar verses can be found in the Letter to the Ephesians or in Letters to the Corinthians. 
in a slightly different way. According to the tradition of nobility, physical work was deprecated as a necessary evil. The impoverished nobles transformed into the intelligentsia, a social group which followed a similar hierarchy of values. For peasants, migrating en masse to the cities, working in factories or other industries did not represent the same value as the previous work on their own farms. As a result, they ended up as the lumpen proletariat; on the other hand, the wealthy bourgeoisie, which at that time was the driving force of change, remained underdeveloped (Jacher, \& Swadźba, 2002, pp. 150-151). The evident shift in Poles' attitude towards work as a value, and other values related or derived from work, did not occur until the beginning of the 1990s, in the period of political transformation (Jacher, \& Swadźba, 2002, pp. 155-156; Sikorska, 2002, pp. 22-45). At this point, it is worth noticing that Christian Protestant values rely on honesty, reliability and diligence (Weber, 1976, pp. 67-72). Weber clearly underlined the difference between behaving in a specific way and obeying certain rules while being continuously controlled (by the state or church police) (Weber, 1976, pp. 152-153). According to Weber, in the environment which I will refer to as Protestant culture, an indefatigable work ethic (Weber, 1976, pp. 125-126), which is connected with striving to live "a holy life", is commended (Weber, 1976, pp. 153-154). Fulfilling everyday duties related to the social status of a particular person became the equivalent of monastic asceticism, which, in turn, significantly contributed to the development of capitalism (Weber, 1976, p. 81). There is a possibility that it was associated with the urbanisation process itself and the bourgeois concept of vita activia, while the medieval and monastic idea vita contemplativa traditionally had more relevance in the countryside. This could explain the development of capitalism in Italian cities, populated mostly by Catholics. The role of urbanisation in the advent of capitalism is undoubtedly an interesting issue and worthy of research. Nonetheless, it goes beyond the scope of this article.

Robert K. Merton refashioned the Weberian model of Protestant work ethics to adapt it to the academic environment. In his opinion, academic ethos is a combination of universalism, communalism, disinterestedness and organised scepticism. Merton understands universalism as a compatibility of statements and previously defined criteria, and observations and previous knowledge (Merton, 1982, p. 581). In the concept of "communalism" of science resides the common ownership of goods, the classifying of discoveries as a product of cooperation (Merton, 1982, p. 584). Disinterestedness, according to R. Merton, cannot be equated with altruism. Rather, it refers to the motives of researchers, whose desire to understand, and capture the essence of, the world should be the result of their concern for the welfare of mankind and its benefit (Merton, 1982, p. 587). The last mentioned feature, organised scepticism, is connected with judgements deferral until gaining a confirmation of facts and an impartial analysis of data (Merton, 1982, p. 589).Whereas M. Weber in his work clearly referred to the principles of Calvinism, R. Merton considered eighteenth-century English Puritanism and closely related Pietism as the most representative sources for his exploration (Merton, 1982, pp. 601621). He showed that these philosophical currents, in their moderate versions, were the foundation of the development of science and technology in England at the dawn of the Industrial Revolution (Merton, 1982, pp. 611-614). They required systematic, even methodical work and restless diligence in the realisation of their calling, which corresponded perfectly with the procedures of scientific experimentation (Merton, 1982, p. 604).Merton's central claim is as follows: "Protestant ethics, expressed in the ideal type of attitudes and values most characteristic of ascetic Protestantism, grabbed the attention of $17^{\text {th }}$ century Englishman and was one of the momentous elements of the 
development of scientific activity. Religious interests, deeply rooted in the ideology of that time, definitely though indirectly encourage the systematic, rational and empiric researching of the phenomena of Nature for the glory of God and to obtain the control over the temporal, broken world" (Merton, 1982, pp. 601-602). In this branch of Protestantism, religion was not isolated from life's others aspects, science was primarily treated in a utilitarian manner and basic assumptions were to serve the welfare of mankind and bring glory to God (Merton, 1982, pp. 603-604). For the scientist, a religious manifestation was taking the toil to complete God's plan. Fulfilling tasks and being active ensured that one's life was dedicated to $\operatorname{God}^{3}$ (Eazarz, 2009, pp. 183). Such an ideal still reverberates in Protestant colleges and universities or lower level schools, whose founders introduce it in internal documents, school mission statements, and graduate profiles ${ }^{4}$. R. Merton formulated the basic principles that underlie the practice of scientific conduct. These key assumptions include freedom of research, condemnation of monastic asceticism, reason and experience as the basis of convictions, faith in science, the existence of nature and world order (Merton, 1982, pp. 608).

The principal statement in Merton's framework is that nominal religious affiliation is not important. What is important are the real beliefs of individuals (Merton, 1982, pp. 613). In line with R. Merton's idea, I think that faithfully professed principles form a foundation for shaping an individual's ethics, reflected also in work ethics, while declaring formal affiliation with denominational or religious movements and referring to principles operating on a collective level does not matter. Scientists believing in the Puritan ethos shaped the academic ethic standards in England, Germany, France, Switzerland or Austria (Merton, 1982, p. 620), creating the canon of rules which are still invoked today. It is hard to state that contemporary academics in the West are deeply religious people ${ }^{5}$, yet there can still be detected the presence of Protestant work ethics in their scholarly practice and, more generally, in their professional life. My assumption is that such an attitude does not depend so much on the individual's faith, but rather, as I argue, it depends on an individual's cultural background or, referring to Pierre Bourdieu, the cultural capital of a social group, or even the habitus, a system of internalised thinking patterns, perception and action, created by its members (Bourdieu, \& Wacquant, 1992, pp. 120-122). Thus, Protestant countries are traditionally based on ethical principles. In traditionally Catholic countries, on the contrary, the creation of academic ethos has to start from scratch.

Is it appropriate to identify work ethos with religion? Considering the specific church affiliation structure in Poland and a strong nominal dominance of the Roman Catholic Church among people of all social classes, Dietrich Bonhoeffer's concept of non-religious Christianity appears interesting. In the darkest era of Nazism, at a time when faith of many people was in crisis, D. Bonhoeffer argued strongly against the "god-of-the-gaps" approach to theology. In a nutshell, he assumed that God was no lon-

3 Łazarz gives examples from a peasant and a farmer life.

4 Take, for instance, the ethos of the Belfast Bible College, Northern Irish, interdenominational Protestant college, http:/ / www.belfastbiblecollege.com/the-college/ethos.php retrieved: 11 August 2012.

5 According to Elaine Howard Ecklund (2010), around 50 \% of academics are believers, which agrees with a similar decreasing trend in the importance of faith in the USA, a country with very strong Protestant traditions, from 1928 till today http://www.pewforum.org/Age/Religion-Among-the-Millennials. aspx\#beliefs retrieved: 4 July 2012. 
ger needed by humans as an explanation for what they cannot understand or control, and that an individual can exist independently, "as if there were no God" (Sarnowski, \& Fryckowski, 1993, p. 127). D. Bonhoeffer searched for an answer to the question of whether religion is a condition of individual salvation for religious people. He expressed his discontent with those who relegate God to the margins of life, where they are unable to cope on their own. This area, however, is dramatically shrinking as people basically are no longer afraid of death (Sarnowski, \& Fryckowski, 1993, p. 129). D. Bonhoeffer's theology shifts the burden of responsibility from God to man. Although in D. Bonhoeffer's case his faith in humanity failed him (he was murdered in a concentration camp during WWII), this concept still has much potential, also in the case of building an academic ethos. Being an academic teacher, as I have mentioned elsewhere, is a complex process of reconciling two roles, which, in fact, requires absolute devotion to one of them. An academic staff member has the dual role of a teacher and as a researcher. Of these two, to the latter is naturally attached more significance. Most PhD students in Poland are primarily taught methodology. They learn modern languages, which allows them to read foreign literature; they broaden their understanding of a particular field of expertise, theories, concepts and paradigms, and they learn how to approach research problems, discover uncharted terrains and explore them. Simultaneously, courses related to teaching students are limited to a bare minimum ${ }^{6}$. A clear emphasis on research can be noticed upon a closer look at university documents created on the basis of the amended Act on Higher Education. One example is a record in the Senate's resolution of the Jagiellonian University in Cracow, which states that "Realisation of the PhD studies program, which prepares the candidate to conduct work in research or research and development, primarily leads to accomplishing learning outcomes in these areas:

1) knowledge to an advanced level, basic in the field of conducted research including the latest achievements in science or art and detailed in the corresponding field of conducted research, including recent achievements in science or art;

2) skills in the areas of teaching methods and methodology of leading research;

3) social competence in the area of research and scientific activity and the social role of the scholar" (Jagiellonian University Senate's resolution from 23rd May 2012). As indicated above, the task of Polish scholars is to work on research projects that will deliver answers to questions bothering those scholars. Polish PhD students are thus more like adventurers than R. Merton's workaholics. Few of them think about becoming academic teachers, treating it as something extra, not a serious task. If they were definitely determined to become teachers, they would probably not choose this career path.

A similar perspective can be observed in the outside gratification of university staff. Awards, honours and financial support in the form of grants go to the best researchers, not to the best teachers (Ministry of Science and Higher Education, Financing), despite the fact that teaching, and not research, is the predominant academic activity at universities (Thieme, 2009, p. 238). Neglect in treating leading courses does not re-

6 For example, see the curriculum for PhD students at the International and Political Studies Faculty, Jagiellonian University, retrieved 11 August 2012 from http://www.wsmip.uj.edu.pl/c/document library/get_file?uuid=b3bf5d8e-e123-4d22-90cc-d35d2fcfbdf4\&groupId=41658 and at the Architecture Faculty, Technology University in Wroclaw retrieved:11 August 2012 from http://doktoranci.pwr. wroc.pl/pliki/programy/2012/program_w1_2012.pdf. 
main unnoticed. Rarely can true commitment in academic teachers be acknowledged, except in a situation where the taught subject matches the area of the instructor's research interests. A simultaneous calling to be a teacher and researcher is also uncommon. For students, passionate and committed teachers mean not only a more interesting course, but also an inspiration for their own academic development (Noga, 2008, pp. 42-47). Problems arise when an academic teacher's passion has nothing in common with his professional life. An unreliable approach to teaching, resulting from lack of preparation, using dated lectures and less effective teaching methods, as well as lack of punctuality, not obeying regulations about assessments, more treating research as a requirement to seasonal reports, the "production" of texts that are methodologically weak and poor in content, publishing in the context of earning "points", not the significance to society or scientific development, are, unfortunately, all commonly observed phenomena (Chmielewski, 2009, pp. 140-151) ${ }^{7}$. This dark picture of Polish academic staff is obviously lightened by a few individuals who treat the tasks given to them with sincere dedication and responsibility.

A different approach can be observed in countries with Protestant traditions. What I have in particular in mind are two centres in the United Kingdom, the Robert Gordon University in Aberdeen, Scotland (a secular school) and the Belfast Bible College in Northern Ireland (a Protestant school), in which I had the opportunity to hold foreign internships ${ }^{8}$. First of all, I noticed a higher level of cohesion between the area of research interest and taught courses, which definitely had an impact on the quality of education. A genuine interest in students' progress manifested itself in different ways in these two schools, which indicates differences in perception of the teacher's professional role - more limited to the academic issues at secular schools and more holistic in a Protestant school. This teachers' involvement is especially apparent in the typically Protestant school, in which the basis for attaching great importance to didactics are anchored in the biblical concept of teaching in the spirit of discipleship. The teacher, or a mentor, both academically and personally, as well as spiritually, transmits knowledge and experience to his/her students. She/he is responsible for their development on all levels, cooperates with students, helping and supporting them. The student-teacher relationship rests on partnership, with friendships outside of the classroom often being established. Mentoring comes as a result of the difference in experience and knowledge; social position is not underlined. At the Protestant school that I visited in all academic or even administration staff statements the theme of God, and the resulting responsibility for fulfilling the task to the best of their ability, was often mentioned. Even though the RGU staff do not directly refer to such arguments, selfless engagement outside of classes, an empathatic approach to students who are going through life difficulties, and weekly meetings of small groups of students with their personal tutors (academic staff members), are secular equivalents based on the same core values. It is treating others with dignity and respect or, to say it in Christian jargon, love of the neighbour.

Probably the first answer in defence of Polish academics would be, that the situation of UK academic staff is entirely different. Certainly, in comparison with teachers from other European Union countries, academic teachers based in Poland are not in a favo-

A. Chmielewski has written extensively on such "pathologies".

8 My own research conducted at the Robert Gordon University between September 2009 and January 2010 and at the Belfast Bible College in May and June 2012. 
urable situation. A German professor earns around $\$ 3,500-3,800$, in the UK $-\$ 3,400$ 3,900 , in Italy $\$ 2,900-3,200$, in Finland \$2,200-2,600 (International Average Salary Income Comparison, Professors), while in Poland it is around \$1,400-2,000 (Average Professor Salary in Poland). It has to be admitted, however, that such statistics are often questioned. For example, Adam Chmielewski, in light of the additional revenues received on account of performed functions, which might even come to 40,000 zł (Chmielewski, 2009, p. 142). This financial perspective aside, it is important to note hierarchical relations resulting from the promotion structure conditioned by academic degrees. The status of an independent academic is granted after around 15-20 years of work (Chmielewski, 2009, pp. 142; Królas, 2012). Before that happens, there is a strong dependence on direct superiors in the professional functioning and possibilities of personal development. This dependence does not decrease after turning into an independent academic: behind-the-scene relationships and agreements, crossing systems of professional-private links still play an important role, albeit their influence is weaker than before ${ }^{9}$. In his book University and Society, Zbyszko Melosik wrote about struggling for dominance of a particular approach, paradigms and discourses. He invokes P. Bourdieu's concept of fields, pointing to the monopoly of scientific competence and the clear aim to preserve the establishment. According to Z. Melosik, the system of promotions represents both the next stage of initiation into the arcane world of the existing system and the approval by novices of the existing canon (Melosik, 2009, pp. 55-60). This situation affects the standard of academics' professional and social life, including colleagues relations and unwillingness to cooperate. An atmosphere of cooperation, of spontaneous creation of research teams, of sharing knowledge and experience is still the exception rather than the rule. Everyday reality is that of fierce competition between staff members, the formation of cliques, favouritism, which has nothing to do with recommending a competent person, clear-cut hierarchy, in which positions are held by the same people and any changes to the existing "balance of power" are met with widespread discontent (Chmielewski, 2009, pp. 142-143).

Recently discussion over a series of scandals touching on similar issues can be observed. One of the most heated debates is caused by the problem of plagiarism. Recent events concerning the disclosure of plagiarism of scientific papers and theses published by widely known and until now respected Polish scholars launched into an avalanche of questions about the causes of such low standards of work ethos among Polish academics (Paper prepared by the Ethics in Science Commission submitted to Minister of Science 16th November 2000). In my opinion, one of the reasons for such low academic standards is the school socialisation process in Poland, whereby children are taught that cheating at tests and exams or using internet ready-papers (in such a way as to not be caught) are widely accepted as they are evidence of cleverness and the life resourcefulness of a child. Without addressing the topic of development conditions at different educational stages, suffice it to draw our attention to adult students. Cheating at tests and exams as well as plagiarism turn out to be a common practice (Academic teachers about studies and students. Research report, 2009). From the lecturers perspective, expecting strict adherence to norms causes cognitive dissonance because it is hard to

9 Remarkably, however, independent academics can have similar experiences. For example one of the Technology University in Wroclaw professors. T. Wysocki, Politechnika Wrocławska ukarała szefa EIT Plus, retrieved 11 August 2012 from http://wroclaw.gazeta.pl/wroclaw/1,35771,11817232,Politechni ka_Wroclawska_ukarala_szefa_EIT_Plus.html. 
hold high expectations towards others if you do not hold them towards yourself. There will not be an atmosphere to build academic ethos on the virtue of honesty when lecturers are inconsistent in their decisions or silently acquiesce to the different violations of norms among students and their co-workers.

Considering three of the afore-mentioned virtues. honesty, reliability and diligence, it is hardly possible not to note that their practical application is not common in the academic environment. As for reliability, there arises a dilemma related to the methodology of the conducted research as well as its content. It also concerns conference presentations and scholarly publications. Not without a reason, they are often treated as publications of lower quality. Articles and conference papers are frequently derivative in content, not bringing any additional value, or they are based on assumptions not supported by any credible research ${ }^{10}$. Potential methodology abuses might result from the flawed sample selection, its size or inadequate research questions at all stages of the conducted research (Paper prepared by the Ethics in Science Commission submitted to Minister of Science 16th November 2000). The general lack of reliability might be partly due to allegations concerning the lack of proper preparation for class, which by students is often reciprocated and perceived as disrespect. A similar problem arises with knowledge assessment. Approval of cheating in exams, papers that are surprisingly similar to other students' papers, or endless lowering of the grading scale is correlated with an easy, common mechanism which applies the same criteria to ourselves. With respect to honesty, a lot has been said: it will be thus enough to comment on the issue of grant competitions and the related processes of filling out applications (false certificates, fictional accomplishments, attempts to submit the same application in multiple copies with only cosmetic changes, etc.) and reporting (double financing, using the same documents in multiple project reports, overstating the costs etc.) (Jajszczyk, 2012). Another problem is the lack of honesty in the presentation of research results, which are frequently manipulated to match the researcher's assumptions. Some scholars even take advantage of their students without acknowledging their students' contribution and engagement, a common practice which rarely meets with any resistance on the part of other scholars. Students get their course marks, the lecturer receives gathered and partly prepared research data, and, to put it colloquially, "everybody's happy". With regard to diligence, it is hard to unambiguously describe the criteria by which this feature should be judged. How much time, energy used for work fulfilment are the required minima? Is the minimum enough to proclaim that this person is diligent? Certainly, there are immeasurable traits of diligence or laziness. An unquestionable minimum is observing working hours, including office hours, the possibility of e-mail or phone contact, at least for students who wish to consult their supervisors. Additionally, if a person serves an administrative function, for example, as Director for the Students, contact should be made possible for all students (Academic teachers about studies and students. Research report, 2009). In this case, I would understand diligence as exceeding the requirements for engagement in research, in the department's everyday life, in the organisation of academic and popularising conferences, in supervising students associations and supporting students initiatives. The fact is that the present state of affairs

10 Publishing after-conference materials (not reviewed) are not counted by the Ministry and they have lower value in the faculty evaluation (state before the changes connected with amendments introduction - until the end of 2010) http://www.mini.pw.edu.pl/ dryzek/www/?S\%B3ownik:Punktacja_za_publikacje retrieved: 12 August 2012. 
is in some way the outcome of a long term policy of turning a blind eye to minor violations (Paper prepared by the Ethics in Science Commission submitted to Minister of Science 16th November 2000).

In view of the above, I think that when aiming to achieve the effect of empowering academic ethos, the building has to start at the foundations. Evidently, in Poland we do not have grounds to establish an academic ethos based on the Western model. Work attitude assumes a long educational process and the socialisation of an individual. In accordance with this (Protestant) ethics, work has its own autotelic as well as instrumental value, which means that it has value in itself and is a way to lead a devout life (Jacher, \& Swadźba, 2002, p. 144), while Catholic ethics in the first place values the results of work, not the work in itself; work has a predominately instrumental value (Jacher, \& Swadźba, 2002, pp. 151-152). Those differences are impossible to overcome. However, it is worth making an effort to mitigate them.

Another aspect, of secondary importance, yet not insignificant, is the legacy of the communist period. Poland's transformation in the 1990s leads to an appreciation of work and its ethos' value. Three factors were especially significant:

- privatisation (running the sole proprietorship or being employed in private owned businesses, in which the owner has particular requirements concerning work performance),

- unemployment or difficulties in finding a job,

- $\quad$ attachment to a position which offers stability and social benefits (Jacher, \& Swadźba, 2002, pp. 155-156).

Obviously, the position of an academic teacher guarantees a stable form of employment, with a relatively low level of unemployment threat (after being employed at the university). It is also not affected directly by the privatisation process and connected with this strong stress on the quality of performance (which in contrast to Academia is present in different areas of the economy). Recently, work ethos has been changing in the direction of greater initiative, including raising qualifications, independence, mobility, readiness to risk and an active approach to job searching (Jacher, \& Swadźba, 2002, p. 158). New challenges occur, and so the old way of thinking does not apply to them (Jacher, \& Swadźba, 2002, p. 159), but the climate of change in Polish academia is still absent.

There have been attempts to implement arbitrarily law regulations ${ }^{11}$. However, this solution remains Weberian police watching over citizens' conforming to regulations. This way means that the code obedience will be still more about avoiding punishment than an internal conviction about the legitimacy of rules or at least conformism. We are still at the stage of pre-conventional morality, perceiving the world in the categories of obedience due to a threat of punishment and fitting rules to achieving individual goals and instrumental exchange of goods (Schaffer, 2006, pp. 330-336). An existing social approval for cheating, lying and perjury, justifying them as moments of weakness, prevents the formation of a law-obeying society, and here academics are no exception. Absence of Protestant legacy, together with a period of fifty years of the People's Republic of Poland, is not a form of self-justification, which explains the present state of

11 In the context of introducing amendments to the Higher Education Law http://www.bip.nauka.gov. pl/_gAllery/13/92/13929/Dz._U._Nr_84__poz._455.pdf retrieved: 11 August 2012. 
work ethic in the Polish academic environment and relieves it from the responsibility for the future. By referring to D. Bonhoeffer's work, I intended to underline the possibilities of searching not only for religious justifications of morality, but also to consider the possibility of building a society based on responsibility for the self and the other. The aim and care of representatives of higher education should be an attempt to build an ethical code of the academic teacher's responsibility. For himself or herself, and for the generalised "Other", who can be a student, a colleague, a superior, or the recipient of their research, and - for those for whom it would be important, before God. This requires Polish society to build a feeling of responsibility and to promote the virtues of diligence, honesty and reliability instead of glorifying easy gain, unclear business practices and mediocrity. To use Margaret Thatcher's words, "there is no alternative" if only those values still are valuable for us.

\section{REFERENCES}

Sarnowski, S., \& Fryckowski, E. (Eds.) (1993). Problemy etyki: wybór tekstów [Ethics Issues: a Selection of Papers]. Bydgoszcz: Agencja Marketingowa "Branta".

Academic teachers about studies and students. Research report (2009). Retrieved from http://www.eksoc. uni.lodz.pl/is/doc/nauczyciele-akademi.pdf.

Average Professor Salary in Poland (n.d.). Retrieved 4 July 2012 from http:/ / www.wynagrodzenia.pl/moja_ placa.php?s=205\&Profesor.

Belfast Bible College Ethos (n.d.). Retrieved 11 August 2012 from http://www.belfastbiblecollege.com/ the-college/ethos.php.

Bourdieu, P., \& Wacquant, L. J. D. (1992). An Invitation to Reflexive Sociology. Chicago: University of Chicago Press.

Chmielewski, A. (2009). Psychopatologia życia politycznego. Podręcznik ilustrowany [Psychopathology of Politics. An Ilustrated Handbook]. Wrocław: Oficyna Wydawnicza ATUT.

Czajkowska, A. (2004), Nauczyciel - doradca, przyjaciel, terapeuta [Teacher - counsellor, friend, therapist]. In: W. Pilecka, G. Rudkowska, \& L. Wrona (Eds.), Podstawy psychologii. Podręcznik dla studentów kierunków nauczycielskich (pp. 487-492). Kraków: Wydawnictwo Naukowe Uniwersytetu Pedagogicznego im. KEN w Krakowie.

Guinness, O. (1998). The Call. Nashville: Word Publishing.

Howard Ecklund, E. (2010). Religion Among the Millennials. Introduction and Overview. Retrieved from http://www.pewforum.org/Age/Religion-Among-the-Millennials.aspx\#beliefs.

International Average Salary Income Comparison, Professors (n.d.). Retrieved 4 July 2012 from http:/ / www. worldsalaries.org/professor.shtml.

Jacher, W., \& Swadźba, U. (2002). Etos pracy w Polsce [Work Ethos in Poland]. In: J. Mariański (Ed.), Kondycja moralna społeczeństwa polskiego [Moral Condition of Polish Society] (pp. 141-151). Kraków: Wydawnictwo WAM.

Jagiellonian University Senate's resolution from 23rd May 2012 (2012) Retrieved from http:/ /www.uj.edu.pl/ documents/1333504/3095875/23.05.2012_uchwala_senatu_nr_58_wytyczne_studia_doktoranckie.pdf.

Jajszczyk, A. (2012). Fala wniosków, ale lekko regulowana [The wave of proposals, but slightly regulated]. PAUza Akademicka. Tygodnik Polskiej Akademii Umiejętności. Retrieved from http://www.ncn.gov.pl/ sites/default/files/pliki/centrum-prasowe/2012.04.19-PAUza-fala-wnioskow.pdf.

Królas, K. (2002). Droga do habilitacji [A Way to Habilitation]. Alma mater. Miesięcznik Uniwersytetu Jagiellońskiego. Retrieved from http://www3.uj.edu.pl/alma/alma/39/01/03.html.

Łazarz, R. (2009). Słowo chrześcijańskiego gospodarza. Uwagi o lekturze „Gospodarstwa” Anzelma 
Gostomskiego [A Word from Christian Landlord. Comments on the „Farm” by Anzelm Gostomski]. In: Z. Pasek (Ed.), Protestancka kultura stowa [Protestant Word Culture] (pp. 175-183). Kraków: Zakład Wydawniczy "NOMOS”.

Melosik, Z. (2009). Uniwersytet i społeczeństwo [University and Society]. Kraków: Oficyna Wydawnicza Impuls. Merton, R. K. (1968). Social Theory and Social Structure. New York: Free Press.

Ministry of Science and Higher Education, Financing (n.d.). Retrieved 8 August 2012 from http://www.nauka. gov.pl/financing.

Noga, M. (2008). Rola nauczyciela akademickiego w rozwoju pasji zawodowej przyszłych nauczycieli [The Role of a Teacher in the Development of Future Teachers Passion]. In: K. Sujak-Lesz (Ed.), Kształcenie nauczycieli w szkole wyższej [Teachers Training in Academia] (pp. 39-50). Wrocław: Centrum Edukacji Nauczycielskiej, Uniwersytet Wrocławski.

Olechnicki, K., \& Załęcki, P. (2000). Stownik socjologiczny [Sociological Dictionary]. Toruń: Wydawnictwo Graffiti BC.

Paper prepared by the Ethics in Science Commission submitted to Minister of Science 16th November 2000. Retrieved from http://kbn.icm.edu.pl/etyka/praktyka.html.

Polish Teachers Association (2010). Declaration about Teachers Professional Ethics - Member of Polish Teachers Association. Retrieved from http://www.znp.edu.pl/element/700/Uchwala_XL_Krajowego_Zjazdu_ Delegatow_Zwiazku_Nauczycielstwa_Polskiego.

Publishing Punctation Rules (by the end of 2010). Retrieved from http://www.mini.pw.edu.pl/ dryzek/ www/?S\%B3ownik:Punktacja_za_publikacje.

Research International Pentor (2008). Public Trust Professions in Poles Consciousness. Retrieved from http:// www.piib.org.pl/pliki/rozne/zawody_zaufania_publicznego_w_swiadomosci_polakow_120308.pdf

Ricken, F. (2011). Etyka ogólna [General Ethics]. Kęty: Wydawnictwo Antyk.

Schaffer, R. H. (2005). Social Development. Oxford: Blackwell.

Sikorska, M. (2002). Zmiany postaw Polaków wobec pracy: lęk przed bezrobociem i samorealizacja [Changes in Poles Attitudes towards Work: Fear of Unemployment and Self-actualisation]. In: A. Jasińska-Kania, M. Maroda (Eds.), Polacy wśród Europejczyków. Wartości społeczeństwa polskiego na tle innych krajów europejskich [Poles among Europeans. Values of the Polish Society on the Background of Other European Countries] (pp. 22-45). Warszawa: Wydawnictwo Naukowe SCHOLAR.

Teachers Ethic Code (n.d.). Retrieved 3 July 2012 from http://www.filozofia-moja.republika.pl/kodeks_ nauczycieli.pdf.

The amended Act on Higher Education from 18th March 2011. Retreived from http://www.bip.nauka.gov.pl/_ gAllery/13/92/13929/Dz._U._Nr_84_poz._455.pdf.

The Curriculum for PhD Students at the Architecture Faculty, Technology University in Wroclaw (n.d.). Retrieved 11 August 2012 from http:/ /doktoranci.pwr.wroc.pl/pliki/programy/2012/program_w1_2012.pdf.

The Curriculum for PhD Students at the International and Political Studies Faculty, Jagiellonian University (n.d.). Retrieved 11 August 2012 from http://www.wsmip.uj.edu.pl/c/document_library/get_ file?uuid=b3bf5d8e-e123-4d22-90cc-d35d2fcfbdf4\&groupId=41658.

The Holy Bible. New International Version (1973). International Biblie Society.

Thieme, J. K. (2009). Szkolnictwo wyższe. Wyzwania XXI wieku. Polska, Europa, USA [Higher Education. Challenges of the $21^{\text {st }}$ Centrury. Poland, Europe, USA]. Warszawa: Difin.

Weber, M. (1976). The Protestant Ethic and the Spirit of Capitalism. London: Allen \& Unwin.

Wysocki, T. (2012). Politechnika Wroctawska ukarała szefa EIT Plus [University of Technology in Wroclaw punished the head of EIT Plus]. Retrieved from http://wroclaw.gazeta.pl/wroclaw/1,35771,11817232,P olitechnika_Wroclawska_ukarala_szefa_EIT_Plus.html. 